\title{
Enhanced and Effective Degradation of Waste Water Treatment for Hydrogen and Bioelectricity Production ${ }^{\dagger}$
}

\author{
Kasipandian Kasirajan ${ }^{1, *}$ \\ 1 Department of Electrical and Electronics Engineering, Faculty of Engineering and Built Environment, MAHSA \\ University, Jenjarom, Selangor - 42610, Malaysia \\ * Correspondence: k.kasirajan@rediffmail.com; \\ $\dagger$ Presented at International e-Conference on Bioengineering for Health and Environment (ICBHE 2020)
}

Received: 5.07.2020; Revised: 10.07.2020; Accepted: 12.07.2020; Published: 15.07.2020

\begin{abstract}
This paper summarises different methods used for the Electrical power generation using microorganisms in Microbial Fuel Cell (MFC), where power generation is done in a microbial environment. Microorganisms are used as catalysts to degrade the supplied source effectively. This bioelectricity production is carried out in an enhanced way in a pollution-free environment. This paper addresses different aspects of electricity generation with the help of microorganisms. Various types of Microbial fuel cells have been described based on their constructional details. One of the different power generation methods is wastewater treatment. Also, hydrogen is generated in this environment, which can be used in fuel cells. Different factors and catalysts used to produce bioelectricity are identified and analyzed. Finally, the power produced in those methods had been compared, and the best method is cited.
\end{abstract}

Keywords: Microorganism; Wastewater treatment; Catalysts; Microbial fuel cell; Hydrogen generation.

(c) 2020 by the authors. This article is an open-access article distributed under the terms and conditions of the Creative Commons Attribution (CC BY) license (https://creativecommons.org/licenses/by/4.0/).

\section{Funding}

This research received no external funding.

\section{Acknowledgments}

This research has no acknowledgment.

\section{Conflicts of Interest}

The authors declare no conflict of interest. 